\title{
Exceptional preservation of embryos in the actinopterygian Saurichthys from the Middle Triassic of Monte San Giorgio, Switzerland
}

\author{
Silvio Renesto ${ }^{1, *} \&$ Rudolf StOckaR ${ }^{2}$
}

Key words: Saurichthys, embryos, soft tissues, phosphatization, Middle Triassic, Switzerland

\begin{abstract}
New excavations in the famous Monte San Giorgio area, close to the historical sites where the Cassina beds crop out (Lower Meride Limestone, Early Ladinian), revealed an interesting vertebrate fauna, including several specimens of the actinopterygian fish Saurichthys. Among the prepared specimens, three specimens of Saurichthys contain embryos, and in one example the embryos
\end{abstract}

are preserved with traces of the soft parts, most probably phosphatized musculature. This discovery is of particular relevance because fossil embryos with preserved soft parts are extremely rare. In addition, although viviparity had previously been described for Saurichthys, the new specimens are rather better evidence and add further support to this reproductive mode.

\section{Introduction and geological setting}

The Middle Triassic carbonate succession of Monte San Giorgio consists of four different formations (Fig. 1). Above the Anisian Salvatore Dolomite lies a $16 \mathrm{~m}$ thick Besano Formation (Anisian-Ladinian boundary), from which the greatest part of the well known vertebrate fauna of Monte San Giorgio has been recovered (Bürgin et al. 1989; Furrer 2003). Overlying it is the San Giorgio Dolomite which, in turn, grades into the well-bedded Ladinian Meride Limestone, reaching a total thickness of 400-600 m.

Among the parallel-bedded calcilutite sequence of the Early Ladinian Lower Meride Limestone three fossiliferous beds are known, each consisting of intercalations of finely laminated, organic-rich black shales, micritic limestones and marls: the Cava inferiore, Cava superiore and Cassina beds. All these beds are interpreted as deposited within intraplatform basins under predominant dysoxic to anoxic conditions (Furrer 1995). Preliminary results of taphonomic and palaeoecological studies in the fossiliferous Cava inferiore and Cava superiore beds were described by Furrer (1999a, b; 2001a, b) and a model of the palaeoecology for the three fossiliferous beds in the Lower Meride Limestone (Cava inferiore, Cava superiore and Cassina beds) was presented by Müller-Merz et al. (2005: fig. 27).
The Cassina beds are named after the locality lying to the south of the summit (Fig. 1), where they were originally investigated in 1933 by the University of Zürich which carried out further excavations in 1937 and between 1971-1975. Together with specimens of the sauropterygians (marine reptiles) Ceresiosaurus lanzi, Neusticosaurus edwardsii, Macrocnemus bassanii and Tanystropheus meridensis, a large ichthyofauna was collected, dominated by examples of wellpreserved Saurichthys curionii and S. macrocephalus (KuhnSchnyder 1974; Wild 1980; Rieppel 1985; Bürgin 1992, 1999; Furrer 1995, 2003; Hänni 2004). In addition, smaller actinopterygians referred to three different genera are also reported: Peltopleurus sp. (one single specimen described and figured by Bürgin 1992), Archaeosemionotus sp. nov. and Macrosemiidae gen. et sp. nov. (both listed in Bürgin 1999, but undescribed).

In 2006, the Museo Cantonale di Storia Naturale (Lugano) undertook a new excavation in the Cassina beds at the type locality, to investigate bed by bed a surface of about $40 \mathrm{~m}^{2}$ through the whole fossiliferous succession. The new site lies nearly $50 \mathrm{~m}$ north of the previous ones.

In the new site the outcrop of fossiliferous beds represent an almost $3 \mathrm{~m}$ thick interval (only a third of it has been excavated so far; Fig. 2) of mainly interbedded finely laminated, organic-rich shales and limestones with intercalated thicker bitu-

\footnotetext{
${ }^{1}$ Department of Structural and Functional Biology, Università degli Studi dell'Insubria, via Dunant 3, I-21100 Varese, Italy.

${ }^{2}$ Museo Cantonale di Storia Naturale, viale Cattaneo 4, CH-6900 Lugano, Switzerland.

*Corresponding author: Silvio Renesto. E-mail: silvio.renesto@uninsubria.it
} 


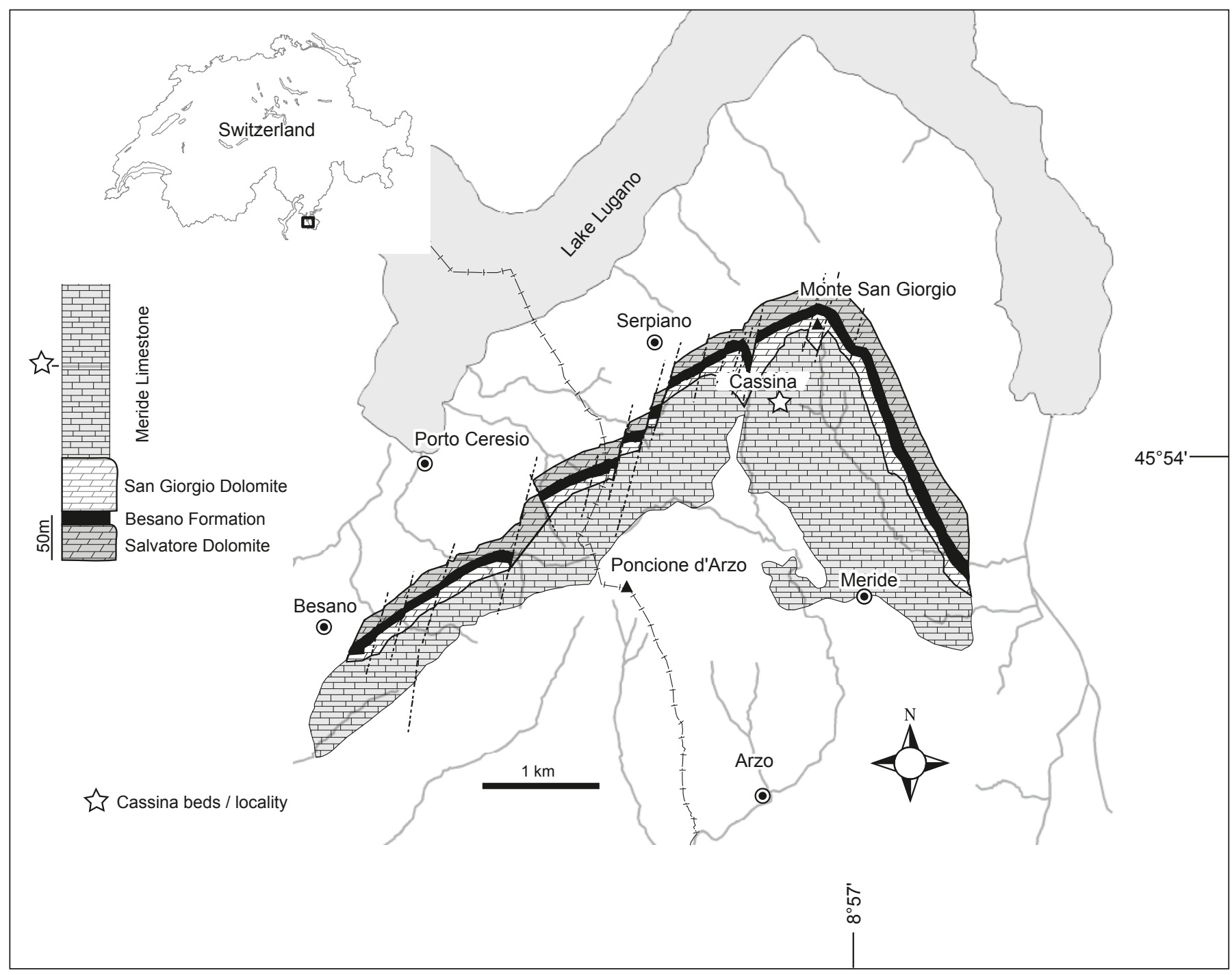

Fig. 1. Map of the Monte San Giorgio area (Ticino, Southern Switzerland), showing the carbonate Anisian-Ladinian sequence together with the locality Cassina.

minous micritic and marly limestones. Lack of bioturbation and physical reworking, and the presence of mostly complete and articulated fossils in the above-mentioned layers point to deposition below storm wave base and in oxygen-depleted bottom water, and thus excluding large benthic organisms. Evidence of a weak current activity of smaller fossils, occurs in a single case in the form of selective orientation but the available data from that bed is too scanty to be conclusive. Normal graded calcarenites, showing erosional surfaces and bearing scattered clearly reworked fossil fragments, suggest the instability of the basin margins and the occasional influence of turbidity currents. Volcaniclastic layers (tuffs and bentonites) are frequent throughout the section.

Along with sauropterygian remains (isolated bones and teeth), the new excavations brought to light many complete and well-preserved specimens of the large (up to $0.5 \mathrm{~m}$ standard length) predatory actinopterygian fish Saurichthys (mainly S. curionii, but S. macrocephalus is also present). Medium sized (15-20 cm standard length) fishes are so far represented by the neopterygian Archaeosemionotus, with semi-durophagous dentition; smaller (less than $10 \mathrm{~cm}$ standard length) actinopterygians, like Eosemionotus (not previously reported from these beds), with elongate, pencil-like teeth effective for picking small organisms from the bottom (Bürgin 2004) and Peltopleurus, probably a schooling fish feeding on small planktonic invertebrates (Furrer 1995), complete the current vertebrate discoveries.

Rare discoveries of macro- and microbenthos, such as the serpulid Spirorbis sp. along with benthic foraminifers, ostracods and dasycladacean algae (mainly preserved in calcareous con- 


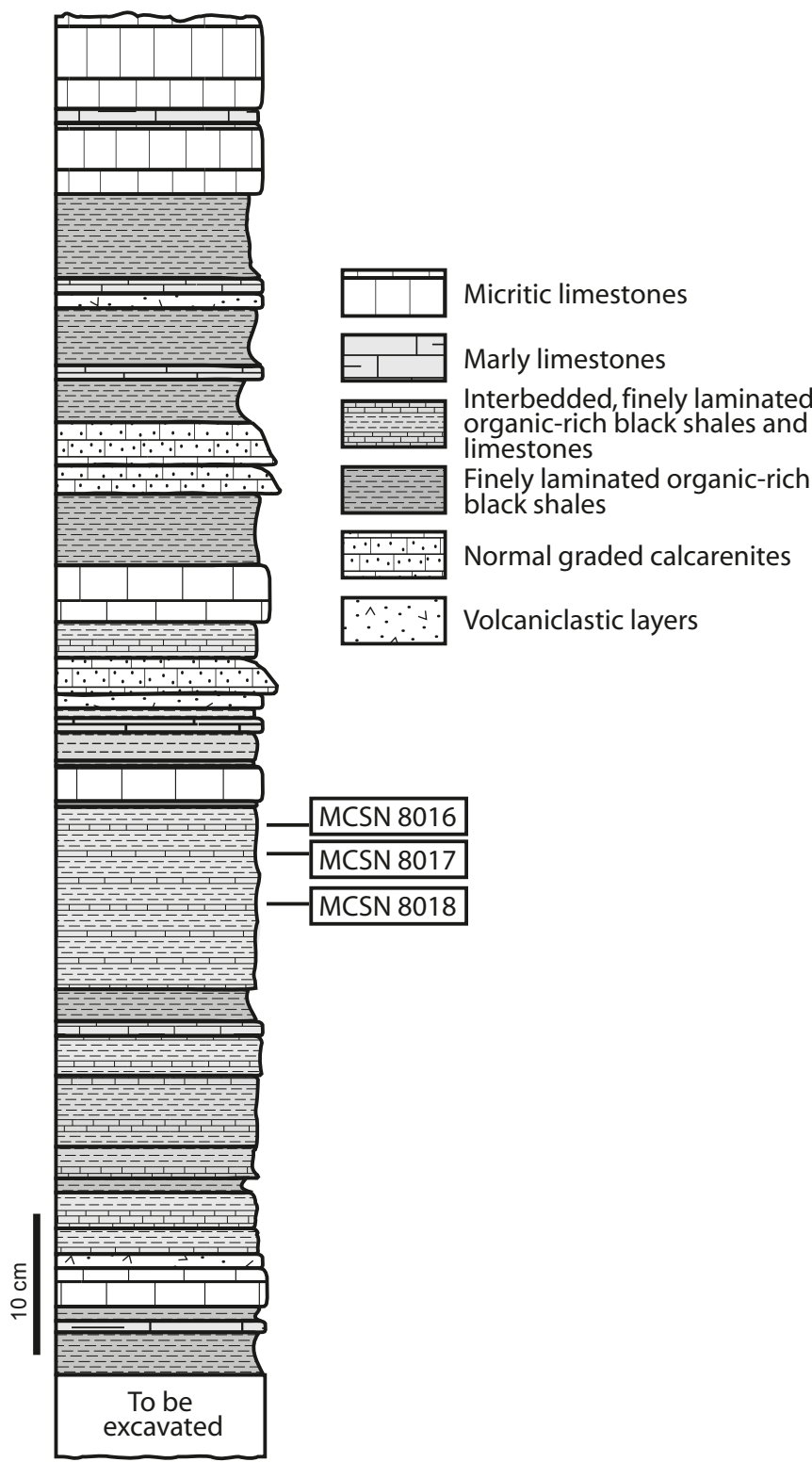

Fig. 2. Detailed section of the uppermost part of Cassina beds, excavated so far. The position of the Saurichthys specimens described herein is indicated. See star in Figure 1 for location of Cassina beds within Meride Limestone.

cretions) are regarded as allochthonous, coming from shallowwater environments of the surrounding carbonate platform and washed into the basin by storms.

The abundance of well-preserved fragments of land plants (mainly conifers) suggests the presence of small islands or larger terrestrial areas nearby (Furrer 1995; Müller-Merz et al. 2005).

Institutional abbreviations. - The three specimens described in this paper are housed at the Museo Cantonale di Storia Naturale (MCSN), Lugano, Switzerland. Comparisons are made with specimens housed in the collection of the Paläontologisches Institut und Museum Zürich (PIMUZ), Zürich, Switzerland.

\section{Systematic Palaeontology}

Actinopterygii WoODWARD 1891

Actinopteri COPE 1871

Chondrostei MÜLLER 1845

Saurichthyidae GOODRICH 1909

Saurichthys AGASSIZ 1835

Saurichthys curionii (BellotTr 1857) (Figs. 3-6)

See Rieppel (1985) for synonymy.

Material. - Three specimens MCSN 8016, MCSN 8017 and MCSN 8018

\section{Description}

The overall body size (about $30 \mathrm{~cm}$ in standard length) and proportions, the long and slender rostrum (approximately $72 \%$ of skull length) with diminutive dentition, the opercular bone approximately as wide as it is tall, and the mid-lateral scales that are triangular, low and rather broad, along with the number of lepidotrichia for each fin allow to attribute all these specimens to $S$. curionii (BELLOTTI) as diagnosed by Rieppel (1985).

\section{Specimen MCSN 8017}

This specimen (Fig. 3a) is incomplete since the tip of the rostrum is missing and the cranialmost portion of the body is obscured by a fault. A dark area outlines the body shape. Within this area at the level of the anteroventral half of the body, in correspondence of the abdominal cavity, at least seven small Saurichthys skulls are visible. Preservation of these skulls is rather poor and mostly only faint remains of the rostrum can be clearly detected along with a dark patch corresponding to the orbit area. These small skulls are almost equal in size and the best-preserved skull is $14 \mathrm{~mm}$ long. Two skulls are oriented cranially while five skulls are oriented caudally and three of the latter are slightly superimposed on each other. The (skull/ length)-ratio between the large and small specimens cannot be calculated due to the lack of the anterior portion of the skull in the large specimen, but judging from its overall size, it has to be similar to that of specimen MCSN 8018 described below.

\section{Specimen MCSN 8018}

This specimen is nearly complete and articulated but the portion of body caudal to the anal and the caudal fin could not be recovered because the stone slab bearing the fossil is crossed by a small fault that displaced the level of several centimetres (Fig. 3b). The preserved portion of the skull is $156 \mathrm{~mm}$ long. In the cranioventral half of the body at least seven small skulls of Saurichthys are present, their preservation being somewhat bet- 

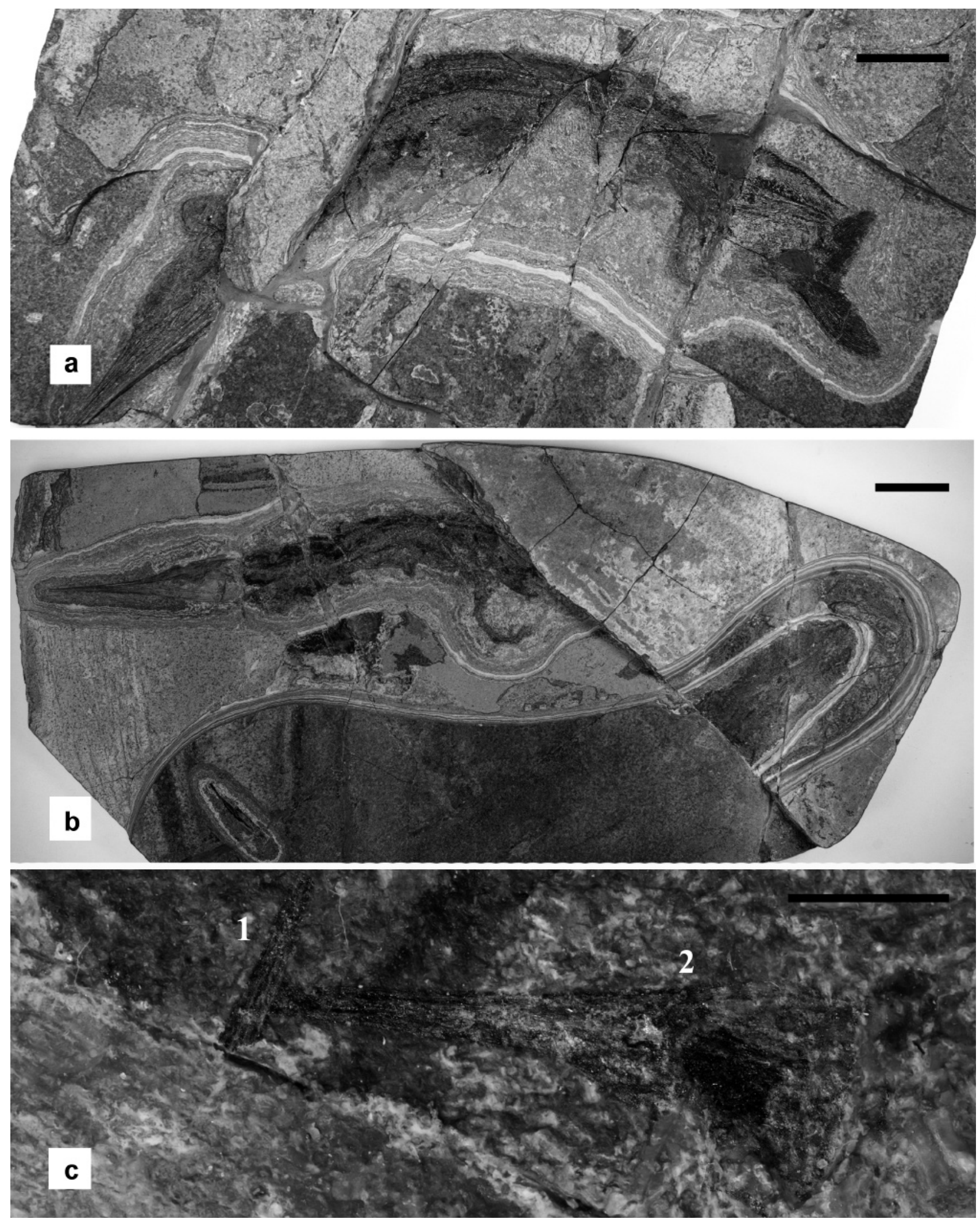

Fig. 3. Saurichthys curionii, specimen MCSN 8017 (a) and MCSN 8018 (b). Close up of a rostrum (1) and a complete skull (2) of embryos from specimen MCSN 8018 (c). The photograph (c) has been digitally enhanced to allow better visibility of the embryo skull, by increasing its contrast with respect to the matrix. Scale bars: $50 \mathrm{~mm}(\mathrm{a}, \mathrm{b}) ; 5 \mathrm{~mm}(\mathrm{c})$. 

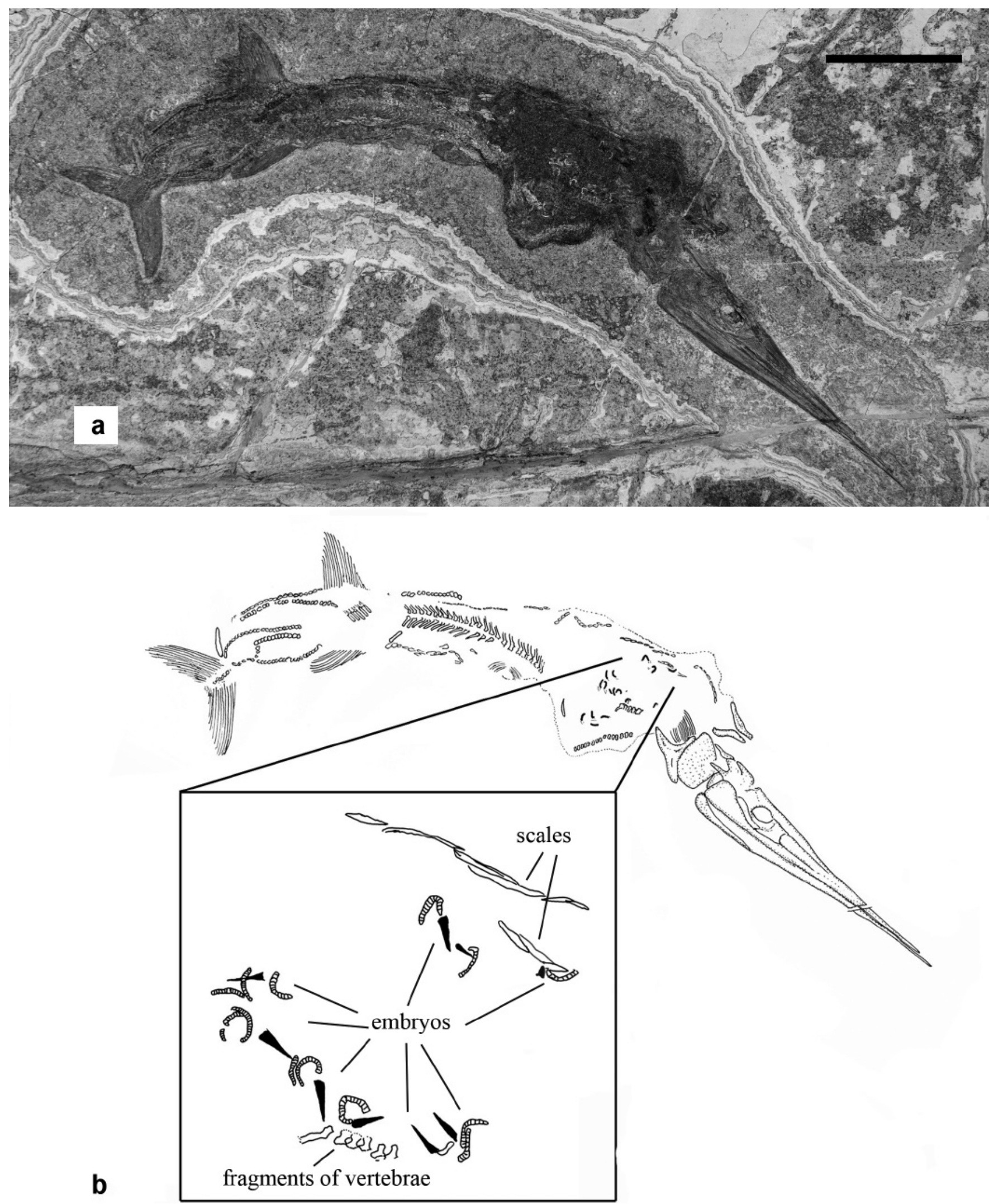

Fig. 4. Saurichthys curionii, specimen MCSN 8016 (a). Sketch of the same specimen (b), stippled contours refer to the dark areas; in the box, an enlargement of the body region with some of the embryos preserved (skulls in solid black and soft parts striped). Scale bar: $50 \mathrm{~mm}$. 

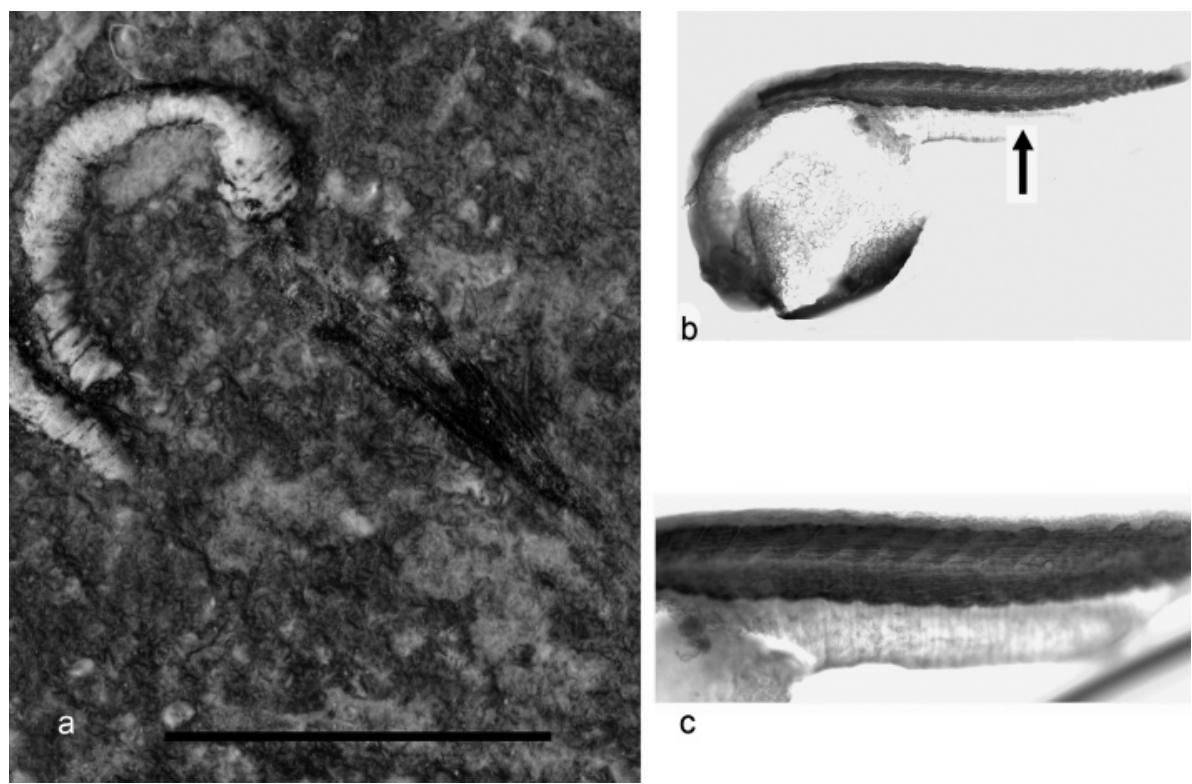

Fig. 5. a) Saurichthys curionii, specimen MCSN 8016, high magnification detail of an embryo. b) Embryo of the extant zebrafish (Danio rerio), in lateral (left) view, processed with antimyosin antibody to show the somites; the arrow indicates the portion of the body enlarged in (c) for a better visualization of the somites. The photograph in (a) has been digitally enhanced to allow better visibility of the embryo skull, by increasing its contrast with respect to the matrix. Scale bar: $5 \mathrm{~mm}$ (a). Figure $5 \mathrm{~b}$ and c are a courtesy of Gianluca Tettamanti.

ter than in MCSN 8017. Four of the small skulls are caudally oriented, two point cranially and one is transverse (dorsoventrally). Three of these skulls lie outside of the line of the ventral scales. All the small skulls are approximately of the same size, the best preserved being $14 \mathrm{~mm}$ long, so that the ratio between the length of the skull of the small specimens and the large one is 0.09 . This ratio is about the same that for the specimen PIMUZT3917 (Bürgin 1990), considered as a gravid female of S. curionii (Rieppel 1985; Bürgin 1990), therefore the reported small specimens can be considered as embryos with some confidence.

\section{Specimen MCSN 8016}

This articulated specimen, exposed mostly on its right side and nearly complete, has a skull $149 \mathrm{~mm}$ in length (Fig. 4a). The contour of its body is approximately outlined by the presence of a thin dark area. The vertebral column is bent and the vertebral series is interrupted at two points, just caudal to the cleithrum, and at the base of the tail. A distinct widening of the dark area of organic matter representing the outline of the body may suggest that the cranial half of the trunk was somewhat expanded after death as though it was inflated then squashed. Within this area (Fig. 4b), sixteen very small skulls are present, their shape being almost identical to those described for the embryos found within the body of specimen PIMUZ T4106 of S. macrocephalus by Rieppel (1985) and Bürgin (1990). Observation of skull characters is even more difficult than in PIMUZ T4106, due to the small size and poor preservation. Only the elongate jaws and a dark patch corresponding to the orbital region are detectable in most cases. As for the previously described specimens, the small skulls (Figs. 4,5) are all approximately of the same size, but much smaller than those contained in the other two specimens, with a mean length of only $6 \mathrm{~mm}$. The (embryo skull length/adult skull length)-ratio is 0.04 , which is similar to the same ratio measured for specimen PIMUZ T4106 (i.e. 0.05; Bürgin 1990).

The preservation of these small specimens, however, shows a peculiarity that was not reported for other embryos attributed to Saurichthys so far because each skull is associated with a tiny, narrow and elongate structure. At higher magnifications (Fig. 5), this structure appears as composed of short and narrow cylinders, that are either curled or comma shaped. The nearly one-to-one association between the embryonic skulls and the narrow cylinders suggests that they may represent some postcranial structure of the embryos. A fourth gravid specimen from the new excavation is currently under preparation; preliminary observation revealed that the size of the embryos it contains is roughly similar to that of specimens MCSN 8017 and 8018 and that no traces of postcranial structures of embryos are preserved.

\section{Discussion}

The identification of these tiny, narrow and elongate structures preserved in specimen MCSN 8016 is problematic. However, it is not plausible that these rod-like structure may represent fossilized vertebrae of the embryos because they are solid cylinders while in Saurichthys vertebrae are C shaped empty rings, and also these structures are too large for this developmental stage to represent the notochord (Ballard \& Needham 1980; Wang et al. 1985). The application of drops of a solution of nitric acid and ammonium molibdate on these structures turned their colour from white to bright yellow, indicating the precipitation of ammonium phosphomolibdate thus revealing their phosphatic nature (Green Owen 2001). Phosphatization may occur for soft parts if the microenvironmental conditions around the carcass allow precipitation of phosphate, as detailed further, however it is difficult to establish which soft part was phosphatized. These

328 S. Renesto \& R. Stockar 

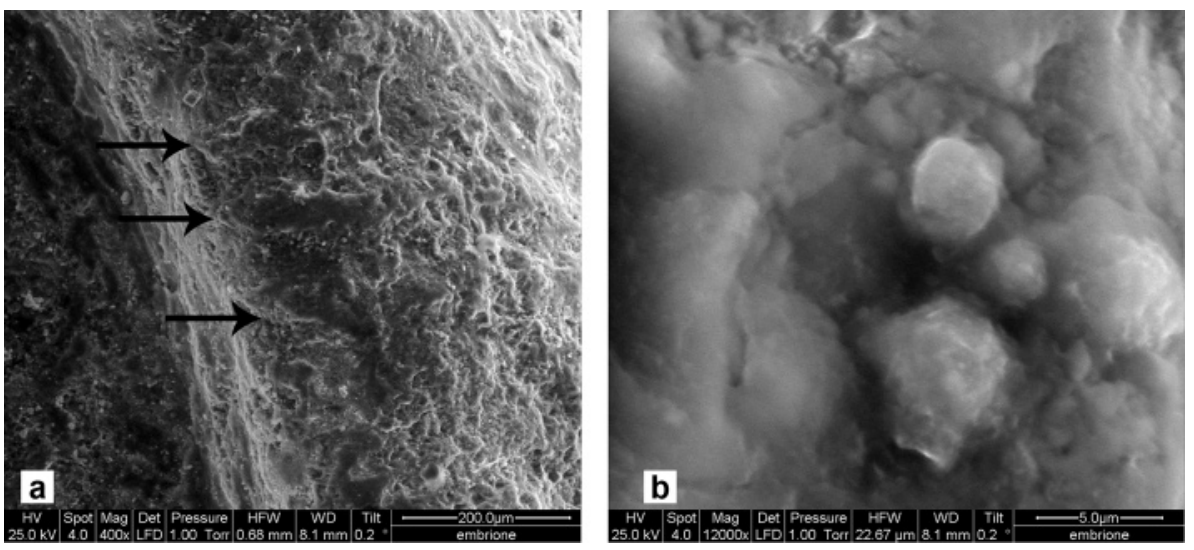

Fig. 6. Saurichthys curionii, specimen MCSN 8016. SEM photographs of a portion of the embryo revealing the metameric structure (arrows) (a), and of a group of supposed lithified bacteria on the embryo surface (b). Scale bars: $5 \mu \mathrm{m}$ (b), $200 \mu \mathrm{m}$ (a).

structures cannot represent remains of the notochord, because their section is too thick, or of the digestive tract, because they are segmented and seem to be too long if compared to the size of the skull. The size and length of these structures with respect to the associated skulls are compatible with the axial musculature (Ballard \& Needham 1980; Wang et al. 1985) and recall the morphology of embryos in extant fishes (Figs. 5b, c). In this case, the curled narrow cylinders may well represent the fossilized musculature of the embryos and each segment could correspond to a somite. A SEM (Scanning Electron Microscope) observation confirms the metameric structure of the cylinder (Fig. 6a), but it was not possible to observe details of muscular fibres, perhaps due to preservational biases. Spheroidal to ovoidal bodies (Fig. 6b), a few microns in size, cover embryos as well as dark areas outlining the body. They are interpreted as lithified bacteria, similar to those reported in Wuttke (1983), Martill (1987) and Schieber (2002). The preservation of muscular mass in the embryos of MCSN 8016 may be due to peculiar conditions of fossilization: possibly the dark area representing the body outline was a consequence of bacterial activity, as occurs in some specimens of the sauropterygian Neusticosaurus (Sander 1989: p. 622), where the dark areas are actually remains of bacterial mats, sometimes with fossilized skin. Preservation of rapidly decaying tissues like muscle, normally requires their replication by rapid authigenic mineralization (Martill et al. 1992). Taphonomic studies suggest that apatite forms in oxygen depleted environments, often in fully reducing conditions (Lucas \& Prevôt 1985) and in presence of organic matter that may also represent the source of the phosphate. This process depends upon the generation of steep geochemical gradients by action of decay microbes (Briggs 2003). Also, experimental evidence (Sagemann et al. 1999) suggests that microbial activity creates microenvironments within the decaying carcass, controlling the mineral species that form during these processes. This activity influences the switch between calcium carbonate and calcium phosphate precipitation, by local variations of the pH (Briggs \& Wilby 1996). According to Briggs (2003) the conditions allowing precipitation of phosphate may be limited only to some area of the carcass, depending on the microbial activity.
The bacterial mat growing on and within the Saurichthys carcass generated a closed environment where the $\mathrm{pH}$ was reduced (Martill 1988), allowing the precipitation of phosphate, that replaced the muscle tissue of the embryos. The decaying muscular mass of the mother body was the source of the phosphate that had been trapped by the bacterial mat, avoiding its dispersion in the surrounding environment. The decay processes possibly prevented the preservation of the fine structure of muscular fibres but only of the muscular mass. This represents the first case of preservation of soft tissues in embryos of Saurichthys.

\section{Concluding remarks}

Evidences of viviparity among fossil actinopterygians are rather scarce (Bürgin 1990). For the Triassic, other evidences have been reported from the Lower Triassic species Birgeria nielseni from Madagascar (Beltan 1977, 1980), and modification of the anal fin suggesting internal fertilization has been found in the Middle Triassic species Peltopleurus lissocephalus (Bürgin 1990) and P. nuptialis (Lombardo 1999) along with the Middle and Upper Triassic species of the genus Saurichthys (Griffith 1977; Rieppel 1985; Bürgin 1990).

The discovery of three further specimens of Saurichthys containing embryos is important to confirm the viviparity in this genus (Rieppel 1985; Bürgin 1990; Furrer 2003: fig. 20), since few other gravid specimens have been found. In addition, the specimen MCSN 8016 is of further relevance, as it is the first example of preservation of soft tissue and postcranial structures in the embryos of Saurichthys by bacterial activity.

\section{Acknowledgements}

Our sincere thanks go to Lionel Cavin (Genève) and David Martill (Portsmouth) for their thorough and accurate review of the manuscript; their comments and remarks greatly improved the paper. Heinz Furrer (Zürich) is acknowledged for the help with the specimens of the collection of the Paläontologisches Institut und Museum Zürich (PIMUZ) and for providing unpublished data about previous excavations carried out by the PIMUZ at the Cassina site. Many thanks also to Toni Bürgin (St. Gallen) for reading a preliminary version of the manuscript giving us useful advices, to Urs Oberli (St. Gallen) 
for the preparation of the specimens, to Giuseppe Vendramin and Cristiana Giordano of the Centro di Microscopie Elettroniche (CNR Florence) for providing facilities and friendly support for the ESEM investigation, and to Remo Pagani (Orpund) the owner of the field in which the site crops out for his permission to make excavations. Gianluca Tettamanti (Dipartimento di Biologia e Scienze Molecolari, Varese) kindly provided the photographs of extant fish embryo. Finally, we wish to thank everybody who took part during the field work for their valuable support. This study was financially supported by the Museo Cantonale di Storia Naturale, Lugano (Ris. 722-08/02).

\section{REFERENCES}

Agassiz, J.L.R. 1835: On the fossil fishes of Scotland. Report of the British Association for the Advancement of Science, British Association for the Advancement of Science, Edinburgh.

Ballard, W.W. \& Needham, R.G. 1980: Normal embryonic stages of Polyodon spatula (Walbaum). Journal of Morphology 114, 465-478.

Bellotti, C. 1857: Descrizione di alcune nuove specie di pesci fossili di Perledo e d'altre località lombarde. In: Stoppani A. (Ed.): Studii geologici e paleontologici sulla Lombardia. Milano, 419-438.

Beltan, L. 1977: La parturition d'un actinoptérygien de l'Eotrias du NordOuest de Madagascar. Comptes Rendus de l'Académie des Sciences de Paris 284, 2223-2225.

Beltan, L. 1980: Eotrias du Nord-Ouest de Madagascar: Étude de quelques poissons dont un est en parturition. Annales de la Societé du Géologie du Nord 99, 453-464.

Briggs, D.E.G. 2003: The role of decay and mineralization in the preservation of soft bodied fossils. Annual Review Earth Planetary Science 31, 275-301.

Briggs, D.E.G. \& Wilby, P.R. 1996: The role of the calcium carbonate-calcium phosphate switch in the mineralization of soft bodied fossils. Journal of the Geological Society 153, 665-668.

Bürgin, T. 1990: Reproduction in Middle Triassic actinopterygians; complex fin structures and evidences of viviparity in fossil fishes. Zoological Journal of the Linnean Society 100, 379-391.

Bürgin, T. 1992: Basal Ray-finned fishes (Osteichthyes, Actinopterygii) from the Kalkschieferzone (Uppermost Ladinian) near Meride (Canton Ticino, Southern Switzerland). Eclogae geologicae Helvetiae 88, 803-826.

Bürgin, T. 1999: Middle Triassic marine fish faunas from Switzerland. In: Arratia, G. \& Schultze, H.-P. (Eds.): Mesozoic Fishes 2 - Systematics and Fossil Record. Pfeil, München, 481-494.

Bürgin, T. 2004: Eosemionotus ceresiensis sp. nov., a new semionotiform fish (Actinopterygii, Halecostomi) from the Middle Triassic of Monte San Giorgio (Southern Switzerland). In: Arratia, G. \& Tintori, A. (Eds.): Mesozoic Fishes 3 - Systematics, Paleoenvironments and Biodiversity. Pfeil, München, 239-251.

Bürgin, T., Rieppel, O., Sander, P.M. \& Tschanz, K. 1989: The fossils of Monte San Giorgio. Scientific American 260, 74-81.

Cope, E. D. 1871: Report on the recent reptiles and fishes of the survey, collected by Campbell Carrington \& C. M. Dawes. U. S. Geological Survey Territory Annual Report 5, 467-476.

Furrer, H. 1995: The Kalkschieferzone (Upper Meride Limestone: Ladinian) near Meride (Canton Ticino, Southern Switzerland) and the evolution of a Middle Triassic intraplatform basin. Eclogae geologicae Helvetiae 88, $827-852$.

Furrer, H. 1999a: New excavations in marine Middle Triassic Fossil-Lagerstätten at Monte San Giorgio (Canton Ticino, Southern Switzerland) and the Ducan Mountains near Davos (Canton Graubünden, Eastern Switzerland). In: $3^{\text {rd }}$ International Symposium on Lithographic Limestones and Plattenkalk. Bergamo, Italy - September 1-5, 1999 (Ed. by Renesto, S.). Rivista del Museo Civico di Scienze naturali "Enrico Caffi”, 85-88.

Furrer, H. 1999b: Aktuelle Grabungen in den Unteren Meride-Kalken bei Acqua del Ghiffo. In: Zoologisches Museum der Universität Zürich: Paäontologie in Zürich. Fossilien und ihre Erforschung in Geschichte und Gegenwart, 87-103.

Furrer, H. 2001a: Taphonomy and palaeoecology of fish beds in the Lower Meride Limestone (Ladinian, Middle Triassic) on Monte San Giorgio
(Canton Ticino, Southern Switzerland). Abstract. International Meeting on Mesozoic Fishes 3 - Systematics, Paleoenvironments and Biodiversity. Serpiano-Meride (Ticino-Switzerland), 26-31 August 2001, p. 29.

Furrer, H. 2001b: Fossil-Lagerstaetten in the Lower Meride Limestone, Ladinian. Guide to the field trip to Acqua del Ghiffo near Crocifisso, Meride TI. International Meeting on Mesozoic Fishes 3 - Systematics, Paleoenvironments and Biodiversity. Serpiano-Meride (Ticino-Switzerland), 26-31 August 2001,1-11.

Furrer, H. 2003: Der Monte San Giorgio im Südtessin - vom Berg der Saurier zur Fossil-Lagerstätte internationaler Bedeutung. Neues Jahrbuch der Naturforschenden Gesellschaft in Zürich 206, 1-64.

Green Owen, R. 2001:A Manual of Practical Laboratory and Field Techniques in Palaeobiology. Kluwer Academic Publishers, Dordrecht, 1-538.

Griffith, J. 1977: The Upper Triassic fishes from Polzberg bei Lunz, Austria. Zoological Journal of the Linnean Society 60,1-93.

Hänni, K. 2004: Die Gattung Ceresiosaurus. Ceresiosaurus calcagnii Peyer und Ceresiosaurus lanzi n. sp (Lariosauridae, Sauropterygia). Vdf Hochschulverlag ETH Zürich, 147 pp.

Kuhn-Schnyder, E. 1974: Die Triasfauna der Tessiner Kalkalpen. Neues Jahrbuch der Naturforschenden Gesellschaft in Zürich 176,1-119.

Lombardo, C. 1999: Sexual dimorphism in a new species of the Actinopterygian Peltopleurus from the Triassic of Northern Italy. Palaeontology 42, 741-760.

Lucas, J. \& Prévôt, L. 1985: The synthesis of apatite by bacterial activity: mechanism. Sciences Géologiques, Mémoires 77, 83-92.

Martill, D.M. 1987: A taphonomic and diagenetic case study of a partially articulated ichthyosaur. Palaeontology 30, 543-555.

Martill, D.M. 1988: Preservation of fossil fish in the Santana Formation of Brazil. Palaeontology 31, 1-18.

Martill, D.M., Wilby, P.R. \& Williams, N. 1992: Elemental mapping: a technique for investigating delicate phospatized soft tissues. Palaeontology 35, 869-874.

Müller, J. 1845: Vergleichende Anatomie der Myxinoiden, der Cyclostomen mit durchbohrtem Gaumen. V. Untersuchungen über die Eingeweide der Fische. Abhandlungen der Deutschen Akademie der Wissenschaften zu Berlin 1843, 109-170.

Müller-Merz, E., Berger, J.-P., Furrer, H. \& Meyer, C. 2005: Paläontologie und Umwelt. Vdf Hochschulverlag ETH Zürich, 92 pp.

Rieppel, O. 1985: Die Gattung Saurichthys (Pisces, Actinopterygii) aus der mittleren Trias des Monte San Giorgio, Kanton Tessin. In: Die Triasfauna der Tessiner Kalkalpen XXV. Schweizerische Paläontologische Abhandlungen 108, 1-103.

Sagemann, J., Bale S., Briggs, D.E.G. \& Parkes, J.R. 1999: Controls on the formation of authigenic minerals in association with decaying organic matter: An experimental approach. Geochimica et Cosmochimica Acta 63, 1083-1095.

Sander, M. 1989: The pachypleurosaurids (Reptilia: Nothosauria) from the Middle Triassic of Monte San Giorgio (Switzerland) with the description of a new species. Philosophical Transactions of the Royal Society of London B 325, 561-666.

Schieber, J. 2002: Sedimentary pyrite: A window into the microbial past. Geology 30, 531-534.

Wang. L.Y., Binkovski F.P. \& Doroshov S.I. 1985: Effects of temperatures on early developement of white and lake sturgeon Acipenser transmontanus and $A$. fulvescens. Environmental biology of fishes, W. Junk Pub., Dordrecht 14, 43-50.

Wild, R. 1980: Neue Funde von Tanystropheus (Reptilia, Squamata). In: Kuhn-Schnyder, E. \& Peyer, B. (Eds.): Die Triasfauna der Tessiner Kalkalpen XXIV. Schweizerische Palaeontologisches Abhandlungen 102, $1-43$.

Wuttke, M. 1983: "Weichtheil-Erhaltung”durch lithifizierte Mikroorganismen bei mitteleozänen Vertebraten aus den Ölschiefern der "Grube Messel" bei Darmstadt. Senckenbergiana Lethaea 64, 509-527.

Manuscript received September 15, 2008

Manuscript accepted April 1, 2009

Published Online first July 20, 2009

Editorial Handling: Jean-Paul Billon-Bruyat \& Daniel Marty

330 S. Renesto \& R. Stockar 